THURSDAY, MARCH 6, I873

\section{HARVESTING ANTS AND TRAP-DOOR SPIDERS}

Harvesting Ants and Trap-Door Spiders. Notes and Observations on their Habits and Dwellings. By J. Traherne Moggridge, F.L.S. (L. Reeve and Co., I873.) THIS beautifully illustrated little book is a good 1 example of what can be done by a careful observer in a very short time. It might have been thought that the habits of European insects were pretty well known, and that a person comparatively new to the subject could not hope to add much to our knowledge. But the fact is quite otherwise, for Mr. Moggridge, in the course of a few winters spent in the south of Europe has, by careful observation, thrown considerable light on the habits and economy of two important groups of insects, and, as regards one of them, has disproved the dogmatic assertions of several eminent entomologists. Nothing is more curious than the pertinacity with which scientific men will often draw general conclusions from their own special observations, and then use these conclusions to set aside the observations of other men. Mr. Moggridge now confirms, in many of their minutest details, the accounts given by classical writers of the habits of ants. These habits were recorded with so much appearance of minute observation, that they bear the impress of accuracy; yet because the Ants of England and of Central Europe have different habits, it was concluded that the old authors invented all these details, and that they were at once accepted as truths and became embodied in the familiar sayings of the time. The ants were described as ascending the stalks of cereals and gnawing off the grains, while others below detached the seed from the chaff and carried it home; as gnawing off the radicle to prevent germination, and spreading their stores in the sun to dry after wet weather. Latreille, Huber, Kirby, Blanchard, and many less eminent authors, treat these statements with contempt, and give reasons why they cannot be true for European species, yet we here find them verified in every detail by observations at Mentone and other places on the shores of the Mediterranean. Mr. Moggridge has, however, supplemented these observations by discovering the granaries in which they are stored (sometimes excavated in solid rock), of which accurate plans are given. $\mathrm{He}$ has seen them in the act of collecting seeds, and has traced seeds to the granaries, from which all husks and refuse are carefully carried away; he has seen them bring out the grains to dry after rain, and nibble off the radicle from those which were germinating; lastly, he has seen them (in confinement) feed on the seeds so collected. Avery curious point is, that the collections of seeds, although stored in very damp situations, very rarely germinate; yet nothing has been done to deprive them of vitality, for on being sown they grow vigorously. The species of harvesting ants observed were, Pheidolemegacephala, Atta structor, A. barbara, and a larger and differently coloured variety of the last. Atta structor is found over a large part of Central Europe, yet, as it has never been observed to lay up stores of seeds in more northern countries, it either has different habits according to locality, or local observers have strangely overlooked its peculiarities. The seeds of more than thirty species of plants were found stored up, none of which were cereals; but at Hyères, M. Germain St.
Pierre has observed these latter stored by ants in such quantities that he thinks their depredations must cause serious loss to cultivators. Thus we have another important confirmation of the statements of the old writers.

The second part of the book gives a very interesting and elaborate account of the curious nests of the Trap-Door spiders of the south of Europe, of which two new forms are described, one of them being constructed by a hitherto undescribed species of spider. The nests previously known have a hinged door at the upper end of the tubular nest, but Mr. Moggridge found another kind with a second door lower down, and also one with a lateral chamber the opening to which, as well as the main tube, is closed by the second door. In these nests the lower door is strong and fits closely, and can be held fast by the spider on the inside, while the upper door is for concealment only, being very thin, but almost always closely resembling the surrounding surface. In many cases it is overgrown with living moss and lichens, and Mr. Moggridge thinks that the spider plants or sows the mosses, having found little bits of moss stuck on to a newly-made door. A curious and instructive observation occurs as to the simple manner in which a protective adaptation may be brought about unconsciously. Having cut away the top of one of these nests and thus left the tube exposed on a surface of bare earth, the spider made a new door in which it stuck pieces of moss from the neighbouring moss-covered bank, thus making its nest very conspicuous by the round patch of green on a surface of fresh earth. The simple and natural habit of covering the door of the nest with any material that grows or lies around it usually leads to concealment, but the above example shows that in doing so the insect does not consciously work with this object. Even more curious is the fact that little spiders onily a few days old construct nests exactly like those of the parent-tubes excavated in the earth, lined with silk and provided with one or two doors and lateral passages, as the case may be, but only about one-sixth the size. Good reasons are given for believing that these small nests are not abandoned, but enlarged from time to time as the occupant grows bigger. Whether the very young spiders build their nests independently of all teaching or experience is a curious point of inquiry to which our author adverts, and as he suggests that it might not be very difficult to rear young spiders from the egg and place them in conditions favourable for their existence, it is to be hoped that he will try the experiment and help to throw light on a subject on which we have so little positive knowledge.

The numerous coloured plates, giving full-sized representations of the spiders and their habitations, are very carefully drawn, and add greatly to the interest of one of the most original and entertaining books on natural history we have met with for some.

Alfred R. WALIAACE

\section{SEPULCHRAL MONUMENTS OF CORNWALL}

Nania Cornubia. A descriptive essay, illustrative of the Sepulchres and Funereal Customs of the early Inhabitants of Cornwall. By W. Copeland Borlase, B.A., F.S.A. (London: Longmans; Truro: Netherton, 1872.) EETING with a recent work on any branch of the M antiquities of Cornwall, by an author bearing the name of Borlase, is so much like falling in with the ancient 